УДК $94(3) \ll 14 »$

DOI: https://doi.org/10.33782/eminak2019.4(28).351

\title{
THE COMMERCIAL SIGNIFICANCE OF THE VENETIAN TANA IN THE 1430s
}

\author{
Evgeny Khvalkov \\ Higher School of Economics (St. Petersburg, Russian Federation) \\ e-mail: ekhvalkov@hse.ru \\ ORCID: https://orcid.org/0000-0003-3688-7638
}

In the XIII-XV centuries medieval Europe has made progress in trade and transition to market economy, which resulted in the foundation of a number of Venetian and Genoese overseas colonies in the Eastern Mediterranean and the Black Sea area. The stability of Pax Mongolica had a positive effect on long-distance trade with the Central and Eastern Asia and India. In the XV century the goods from the Eastern Europe prevailed over those from the Central and Eastern Asia, especially the slaves. In exchange the Venetians and the Genoese imported cotton, woolen, and silk fabrics, raw cotton, rice, soap, glass, ceramics, jewellery and swords. The stabilization in the region and the rise of trade was a trend running through the first half of the fifteenth century. The 1430s were the time of the greatest prosperity of the Venetian trade in the Northern Black Sea during the whole fifteenth century.

keywords: Venice, Genoa, colonies, Tana, Black Sea region, market, long-distance trade

This article is devoted to the commercial significance of the Venetian colony in Tana in the 1430s. The shaping of early capitalism, its institutions and mechanisms of the exchange in the late medieval Mediterranean is evident to most researchers, especially as it comes to the trade maritime republic of Venice. The Levant and the Black Sea formed a stable economic unity, which was necessary for Europe both related to imports (textiles and other goods of European industry), and to exports (mainly raw materials). The Eastern Mediterranean was also a transit zone connecting Europe with the Central and Eastern Asia. One of the vividly discussed problems in contemporary historiography is whether the Venetian and, more generally, Italian Black Sea trade declined in the fifteenth century chiefly because of the economic or political (i.e. the Ottoman expansion) reasons. The author's argument here is that judging from the sources we can see in the 1430s a steady increase in trade. Previous historiography mainly claimed that the second half of the fourteenth and the fifteenth century were a period of decline of the Italian longdistance trade with Central and East Asia, specifically in Tana, and of the regionalization of trade and shift of the commercial interest towards local products and local exports (salmon fish, caviar, bread, wax, leather, salt, furs and slaves). At the same time, it is believed that Genoa adapted to the changes that took place better than Venice and conducted transit trade. Studying the notarial documents, the author examined the range of goods that were sold in Tana in the 1430s. Regional commodities were significant indeed; however, apparently, long-distance trade did not decline at all. Repeated mention of silk, undoubtedly of eastern origin, was a sign of intensive trade; on the other hand, obviously, European cloth was imported into Tana in an amount that clearly exceeded the needs of the Italian population of the colony; it means that they were already in demand among local residents. Further, the amount of incanti and the volume of trade showed a steady upward trend, and the Black Sea navigation of the Venetian galleys was significant. This means that the commercial environment gradually became favorable again, and long- 
distance trade regained its positions. Although the Ottoman conquest of Constantinople put an end to this rise of trade, our data confirms the thesis that in the XIII-XV centuries the Italian trade in the area was prosperous and it demonstrated the feature of the European capitalism: raw materials from the East in exchange for goods from European industry.

The relevance of the study of various aspects of the history of the Venetian and Genoese Tana is justified since it shows the allows us to reconstruct the history of international political, economic and cultural ties of the Northern Black Sea Region with the Russian principalities, Western Europe, Byzantium, the Golden Horde, Central Asia and Middle East. The Venetian and Genoese documentary sources originating from the Black Sea region are of crucial importance in such a study. The documents of the Venetian Senate and the notarial deeds drawn up in Tana have long attracted the attention of researchers, being one of the main sources on the economic, political and social history of the Black Sea region. A significant part of these sources were not published previously and did not serve as the subject of a special study, and this once again confirms the relevance of studying acts of Venetian notaries in Tana.

Moving to an overview of historiography one should say that the interest in the history of the Italian trading stations has a long tradition, starting with such names as W. Heyd, F.K. Brun, M. Volkov, M.M. Kovalevsky, V.N. Yurgevich, and L.P. Kolly. The Romanian authors N. Iorga and his successor, G. Bratianu made a great contribution into the field as well. Further studies by F. Melis and G. Pistarino deepened our knowledge of the Italian presence in the East. Many important problems were discussed by F. Thiriet and M. Balard, F. Lane, R. Müller, Ch. Verlinden, M. Nistazopulu-Pelikidis and M. Martin, as well as by S.P.Karpov, A.L.Ponomarev, A.A. Talyzina, N.D. Prokofieva. Still, there is enough room left for current research, analysis and comprehensive study of documentary sources.

The main aim of this article is to figure out the commercial significance of the Venetian Tana in the 1430s and to answer the question whether the effects of the general crisis of the fourteenth century lasted into the fifteenth century resulting in a decline of the longdistance commercial activity and the so-called 'regionalization' of trade.

By the mid-thirteenth century medieval Europe has made some progress in the adoption of the republican system, expansion of trade and transition to market economy. In the XIV-XV centuries the European trade with the East via the Black Sea area expanded; it was indeed the époque of the development of new trade routes and the emergence of the Italian overseas colonies. The stability established by the Mongol conquest had a positive effect on long-distance trade. Although Genoa began colonizing the area before, its main competitor, Venice, came to the region and founded trading stations in Tana and Trebizond. In this long-distance trade with the Central and Eastern Asia and India, the profit was formed due to the difference between production costs in different regions ${ }^{1}$. The range of exported goods was quite broad, although in the XV century the goods from the Eastern Europe prevailed over those from the Central and Eastern Asia, especially the slaves, which were exported from the area since the times of the Bosporan Kingdom². In

\footnotetext{
${ }^{1}$ Карпов С.П. Итальянские морские республики и Южное Причерноморье в XIII-XV вв. Проблемы торговли. Москва, 1990. С. 210.

2 Узлов Ю.А. К вопросу об итальянской колонизации Северо-Западного Кавказа в XIII-XV вв. // Причерноморье, Крым, Русь в истории и культуре. Материалы II Судакской международной научной конференции (12-16 сентября 2004 г.). Часть II. Киев; Судак, 2004. С. 218-219.
} 
exchange the Venetians and the Genoese imported cotton, woollen, and silk fabrics, raw cotton, rice, soap, glass, ceramics, jewellery and swords. All trade in the region was under strict control of the administration of the trading station ${ }^{3}$, and all the foreign policy of the Italian maritime republics in relation to the Eastern countries was mainly to provide the most favourable trade regime and the regime of taxes, tolls and duties ${ }^{4}$. For example, in the policy of Venice towards Byzantium one can identify several areas designed to provide fiscal benefits for its citizens. First, it is a struggle for the reduction or abolition of tolls and duties, chiefly commerchium. The Venetians failed to achieve a complete abolition of this tax, but managed to reduce its initial rate by almost half, to $2 \%$. The second is a claim for damages arising from an arbitrary tax increase or a claim for the return of property confiscated for non-payment of taxes. The third direction is the desire to prevent the abuse of merchants. Finally, the fourth area is unification of measures for tax collection. Thus, the policy of Venice towards the Byzantine Empire mainly was meant to extend the privileges, to guarantee the safety of traffic, and to obtain reparations and compensations. The Tatars usually charged the lowest fee from the Genoese; the Venetians paid a higher commerchium 5 . In general, the Italian merchants settled in the Northern Black Sea region largely due to the fact that the khans of the Golden Horde were well aware of the importance of the international trade in their territory and realized the possible profits from trade for their treasury ${ }^{6}$.

The Venetian trade in Tana often went through hard times and almost constantly faced certain difficulties. First of all, they had a competitor on their way, namely the Genoese, who settled in the Azov sea region in Tana and other settlements on the Azov coast of the North-West Caucasus7. Only in 1332 the Venetians managed to legally formalize their trading station in the embouchure of the River Don under the treaty forged with the Öz Beg Khan ${ }^{8}$. Following this treaty Tana became, alongside with Caffa, Trebizond and Soldaia, the crossroads of naval and landed routes from West to East in the XIV-XV centuries $^{9}$. However, the conflicts of the mid-fourteenth century combined with a pandemic of plague, the war between Venice and Genoa (1340-1355), the civil wars in the Byzantine Empire (1341-1355) and in the Empire of Trebizond (1340-1355), the disintegration of the Ilkhanate and of the Golden Horde (the so-called 'Velikaya Zamyatnya') and the general crisis of the mid-fourteenth century greatly reduced the reliability and security of the long-distance trade in the course of the second half of the fourteenth century ${ }^{10}$ and affected the economy of the Italian maritime trade republics. Consequently, the main trade routes to Levant, Central Asia and China were paralyzed, and the entire system of international trade between the West and the East was disrupted ${ }^{11}$. In the 1370 s and later on,

\footnotetext{
${ }^{3}$ Ibid. C. 218-219.

${ }^{4}$ Карпов С.П. Итальянские морские республики... С. 312.

${ }^{5}$ Карпов С.П. Венецианско-трапезундский конфликт 1374-1376 гг. и неизвестный мирный договор 1376 г. // Византийский временник. Т. 39. Москва, 1978. С. 110.

6 Скржинская Е.Ч. Венецианский посол в Золотой Орде (по надгробию Якопо Корнаро, 1362 г.) // Византийский временник. Т. 35. Москва, 1973. С. 110.

7 Узлов Ю.А. К вопросу об итальянской колонизации... С. 214.

8 Карпов С.П. Документы по истории венецианской фактории Тана во второй половине XIV в. // Причерноморье в средние века / Под ред. С.П. Карпова. Вып. 1. Москва, 1991. С. 191.

9 Карпов С.П. От Таны в Ургенч - эти трудные дороги Средневековья // Средние века. Вып. 61. Москва, 2000. С. 218.

10 Скржинская Е.Ч. Венецианский посол в Золотой Орде... С. 111.

11 Карпов С.П. Кризис середины XIV в.: недооцененный поворот? // Византия между Западом и Востоком. Опыт исторической характеристики / Отв. ред. акад. Г.Г. Литаврин. Санкт-Петербург,
} 
the profitability of the Italian trade with the East was decreasing12. However the decrease in trade in the commodities coming from the Central and Eastern Asia was paralleled by an increase in the share of commodities from Eastern Europe ${ }^{13}$ - grain, wax, fish etc. There were a number of factors that impeded the Italian trade through Tana. After all, the Venetians had to compete with the Genoese; and yet, despite all difficulties, we have evidence of the intensive Venetian trade in the Black Sea region.

Because of the crisis of the mid-fourteenth century and other outbreaks of instability, in the early fifteenth century the security of the trade routes was no longer guaranteed as much as in the early fourteenth century; ${ }^{14}$ and still in the fifteenth century there was a new rise of Venetian and Genoese trade. After a significant decline, the commercial activity in the trading stations in the Northern Black Sea region increased again and the consequences of the crisis of the mid-fourteenth century were gradually overcome both in Europe and in the Black Sea colonies. In general, by the fifteenth century most European countries finished the transition to monetary rent and sharply expanded their domestic markets due to the involvement of peasant economy in the market exchanges. Stable economic relations now linked previously isolated economic regions of the Northern Europe and the Mediterranean. In the XIV-XV centuries the representatives of trade and banking dynasties and companies from Florence, Genoa, Venice, Lucca and other cities of Italy have created a strong and extensive network of its branches, offices and trading posts in most European countries ${ }^{15}$. The XV century is characterized by the general growth in trade turnover, increase in the size of transactions, the emergence of the different types of shopping and banking companies instead of the old merchant guilds or alongside with them. Mass consumer goods, in particular grain (traditionally exported from the Northern Black Sea region since classical antiquity), began to occupy an increasingly important place in the structure of trade ${ }^{16}$. In the late XIV - early XV century Venetian trade reached peak ${ }^{17}$. During this period, the role of the long-distance trade with China and Central Asia decreased; however, at the same time the Venetians were actively exploiting the two vital trade routes - the route of the galleys of Romania and the route of the galleys of Flanders. The trade of the Venetians with Flanders is reflected in the deed drawn in Tana. Thus, according to the will of Michele de Matteo de Suazio from Tana, his heirs should have received thirty one ducats from Pantaleone di Dulcigno, which he borrowed from Michele de Matteo in order to sail to Flanders ${ }^{18}$. The budget of the Republic of St. Mark suffered from the crisis of the mid-fourteenth century less than the budgets of most European monarchies. According to Fernand Braudel, the total income of the Venetian Republic equalled about 1.615 million ducats per year in 1423, by the time of the death of Doge Tommaso Mocenigo; this means that Venice was the absolute leader among the European states in terms of annual income. Its funds invested in trade each

1999. С. 220-238. Карпов С.П. Кризис Таны 1343 г. в свете новых источников. // Византийский временник. Т. 55 (ч. 1). Москва, 1994. С. 121.

12 Карпов С.П. Венецианско-трапезундский конфликт 1374-1376 гг.... С. 103.

13 Талызина А.А. Венецианский нотарий в Тане Кристофоро Риццо (1411-1413) // Причерноморье в средние века / Под ред. С.П. Карпова. Вып. 4. СПб., 2000. С. 28-29.

14 Карпов С.П. От Таны в Ургенч... С. 222.

15 Чистозвонов А.Н. Итальянская и нидерландская экономика и торговля // Средние века. Вып. 41. Москва, 1977. С. 45.

16 Ibid. C. 39.

17 Ibid. C. 45.

18 Cм.: Archivio di Stato di Venezia. Notarili Testamenti. Busta 750 (ASV. NT. Busta 750). f. 23r. 
year equalled 10 million ducats.

With regard to the importance of Tana in the system of the Venetian economy during this period, the sources related to the Venetian expeditions of galleys of Tana allow assessment of the trade volume ${ }^{19}$. Federico Melis thought that Tana was one of the seven main angles of the «world economy» in the late Middle Ages (Bruges - London - Lisbon Fez - Damascus - Azov - Venice) ${ }^{20}$. As the Venetian commercial interests shifted more and more towards trade mediation between Asia Minor and Western Europe, the importance of the naval ways increased 21 . The Republic of Venice established and sought to maintain regular communication with the distant ports of the Black Sea area22, and for many years Tana (Azov) has been the most important trading point between Europe and Asia, and besides that a rich fish market. The reduction in the volume of trade with the Eastern Asia did not result in its extinction. Tana remained gates to Astrakhan, Sarai, Central and Central Asia, connecting the Black Sea with the Volga region. The way from Tana to Astrakhan took from twelve (on camels) to twenty five (on oxen) days. From Astrakhan there was a way to Khanbaliq (Beijing) through Sarai, Urgench, Otrar and Almaliq. Sometimes merchants had to spend the winter in Tana or Astrakhan, if the ice prevented them from moving along the rivers. All the way from Tana to China lasted 284 days ${ }^{23}$. The Black Sea ports also received valuable commodities from India and China ${ }^{24}$.

The role of Tana for Venice and Genoa was not the same. For the Genoese Tana was just a transit point of goods among the River Don valley, Astrakhan, Caffa and Genoa. Despite the remoteness of this port and the closure of navigation in the winter months, it attracted merchants and seafarers. Tana hosted an annual summer fair that attracted caravans from the Volga and the Transcaspian area, from Indian and China ${ }^{25}$. However, while Genoa had in the Black Sea basin a network of colonies with an administrative center in Caffa ${ }^{26}$, Venice had in the Black Sea region only two trading stations, those in Trebizond and Tana, which encouraged the Venetians to hold on to them ${ }^{27}$. Venice sought to preserve the Tana by all means, even in those years when it had to suffer obvious financial losses ${ }^{28}$. Sending the galleys of Tana was also a matter of prestige for the Venetian Republic, which used even the extreme measures under unfavorable conditions so as not to stop navigation ${ }^{29}$, since game was worth the candle: despite all the political hardships, in the fifteenth century there has been a significant growth of trade.

\footnotetext{
19 Карпов С.П. Путями средневековых мореходов: Черноморская навигация Венецианской Республики в XIII-XV вв. Москва, 1994. С. 124-134.

20 Melis F. La civiltà economica nelle sue explicazioni dalla Versilia alla Maremma (secoli X-XVII) // Atti del 60o Congresso internazionale della «Dante Alighieri», P. 21.

21 Воробьева И.Г. Венецианская республика и югославянские земли в XV-XVII веках. Калинин, 1987. C. 9.

22 Карпов С.П. Порты Пелопоннеса в системе торговой навигации венецианских торговых галей в Черном море (XIV-XV вв.) // Средние века. Вып. 59. Москва, 1997. С. 49.

${ }^{23}$ Карпов С.П. От Таны в Ургенч... С. 220.

24 Узлов Ю.А. К вопросу об итальянской колонизации... С. 215.

25 Колли Л.П. Хаджи-Гирей хан и его политика (по генуэзским источникам). Взгляд на политические сношения Каффы с татарами в XV веке // ИТУАК. № 50 (год двадцать шестой). Симферополь, 1913. С. 106.

26 Карпов С.П. Документы по истории венецианской фактории Тана... С. 191-192.

27 Ibid. С. 191-192; Узлов Ю.А. К вопросу об итальянской колонизации... С. 191-192.

28 Карпов С.П. Греки и латиняне в венецианской Тане (середина XIV - середина XV вв.) // Причерноморье в средние века / Под ред. С.П. Карпова. Вып. 7. Москва; СПб., 2009. С. 166.

29 Климанов Л.Г. Обретение Венецией моря: право, политика, символы // Причерноморье в средние века / Под ред. С.П. Карпова. Вып. 3. СПб., 1998. С. 170.
} 
The range of commodities traded through Tana in the space linking Europe with Sarai, Astrakhan and Asia up to China was quite broad: silk, spices, fur, salmon, caviar, bread, wax, fur, textiles and, in particular, slaves ${ }^{30}$. Generally, the trade profit was generated due to the difference in prices of goods in different regions. For example, the difference in prices on textiles between the ports of the Black Sea and Italy was the most significant: in the mid-fifteenth century it varied from from 83 to $150 \%$, which is much higher than in the XIII century, while the difference among the black sea ports was small, not exceeding about $15 \% 31$. It is now common knowledge that, despite the degradation of the Byzantine imperial court and in spite of the extreme impoverishment of the urban population of Constantinople, the markets of the capital of Byzantium were still attractive and the Black Sea direction of trade did not lose its value in international trade for foreign merchants ${ }^{32}$.

The commercial significance of Constantinople and Pera ${ }^{33}$ in this era was due to several reasons:

a) the key location of the city at the junction of old established trade routes coming from the Black Sea, from East and West;

b) the role of Constantinople as a place of international trade, a transit point for such commodities as Tana wax, leather, furs, slaves, copper, exported from this region to Syria, Egypt, and Western Mediterranean;

c) the privileged position of Western merchants in Constantinople (the Venetians and the Genoese did not pay any duties and tolls, and the Florentines, Anconetani and the Catalans paid only $2 \%$ of the value of goods ${ }^{34}$.

The turnover of the Venetian trade with Constantinople (and therefore to a large extent with the Northern Black Sea coast) was, according to the auctions of the galleys of Tana and the books of accounts, about at least 1 million yperpyra per year, and the difference in the prices of goods exported from the Black Sea region between Constantinople and Venice was in the 1430s - 1440s, according to Giacomo Badoer, less than the difference in the price of goods of Oriental origin ${ }^{35}$. The Italians significantly increased the turnover of trade and reduced the trading costs. Goods could be purchased in Tana and then resold in Constantinople to the merchants who exported them to the West. The multi-level trade turnover, of course, affected the prices. Although Venetian trade was impeded by the constant rivalry with the Genoese, who tried to deprive the Venetians of access to the Sea of Azov, as well as it was impeded by the constant threat of the Tatar invasion, it was never completely interrupted. The Tatar attacks on Tana in 1410 and 1418 seemed to undermine the economy of the trading station just for a short while, but the city was rebuilt each time. Venice still constantly sent the galleys of Tana ${ }^{36}$. Moreover, in the fifteenth century the conflicts of Venice and Genoa no longer resulted in large-scale wars between these trade republics, but rather resembled the diplomatic game of the

\footnotetext{
30 Карпов С.П. Документы по истории венецианской фактории Тана... С. 192-194; Узлов Ю.А. К вопросу об итальянской колонизации... С. 192-194.

31 Карпов С.П. Итальянские морские республики... С. 216.

32 Шитиков M.M. Константинополь и венецианская торговля в первой половине XV в. по данным книги счетов Джакомо Бадоэра // Византийский временник. Т. 30. Москва, 1969. С. 49.

33 Oikonomides N. Hommes d'affaires grecs et latins à Constantinople (XIIIe - XVe siècles). Montreal; Paris, 1979.

${ }^{34}$ Heyd W. Histoire du commerce du Levant au Moyen âge. Leipzig, 1885. T. 2. P. 258-259.

35 Шитиков М.М. Константинополь и венецианская торговля... С. 50.

36 Климанов Л.Г. Обретение Венецией моря: право, политика, символы // Причерноморье в средние века / Под ред. С.П. Карпова. Вып. 3. СПб., 1998. С. 170.
} 
republics with the use of their allies - the Tatars of Crimea and the Principality of Theodoro, and Venetians won more often than lost in this game in the 1430s, which increased the safety of their own positions in the Northern Black Sea region.

Normally, the expensive and light goods like spices, cloth, silk, jewellery, fur, etc. were transported on galleys, while the heavier and cheaper goods like grain, salt, wine, oil, slaves were mainly transported on private 'round' ships ${ }^{37}$. So one should conclude that the 1430s were a period of the rise of European trade with the Black Sea area and the growth of regional trade. It is only after 1453 , and due to the political rather than to economic reasons, that this navigation from Venice to Constantinople, Trebizond and Tana was interrupted; it resumed only in 1479 , already on the new grounds, however, in the interim the galleys were send only seven times ${ }^{38}$.

The mechanism of the influence of the commercial activities of the Venetian and Genoese merchants on the economy and social structure of the Byzantine cities is not fully studied $^{39}$. Greeks, Armenians and Jews are sometimes mentioned in the notarial deeds; apparently, the Greeks occupy a significant niche in trade, but still the main role belonged to the Venetians and Genoese. However, the thesis of Michel Balard that the Greeks as well as other Oriental groups of population were completely outplaced in the international trade by the Italians ${ }^{40}$ provoked reasonable doubt and was rejected by S.P. Karpov ${ }^{41}$. As the data of the notarial deeds confirms, the Italian trade did not result in the extinction of the local businessmen, but rather but sought to cooperate with them as with junior partners ${ }^{42}$.

Undoubtedly, with the growing instability on the Eurasian routes some reorientation to local exports took place in Tana ${ }^{43}$. However, it was pointed out that the shift in the commodities by no means equals the 'regionalization' of commerce or the decline of the long-distance trade, but rather a change in directions ${ }^{44}$. In the fifteenth century the fish and caviar trade was of particular importance, as well as the slave trade. On the other hand, traditional Asian commodities (spices, silk, gems) at the time were of minor importance; it is unlikely, however, that they disappeared completely. In the deeds drawn in the 1430s, silk remained one of the main articles of trade and we should not underestimate its importance. Thus, the decision of the Venetian Senate related to the equipment of the galleys of Romania (and therefore Tana) dated May 28, 1434 mentions spices, wax, silk for export to Venice and Constantinople, as well as dyes for textiles ${ }^{45}$. Thus, the relations with the Volga region and the Central Asia did not disappear. Moreover, slave trade was quite vivid. Constantinople, Trebizond and Caffa were the most stable trade partners of

\footnotetext{
37 Карпов С.П. Венецианский документ XV в. о торговой навигации в Восточном Средиземноморье // Византийский временник. Т. 52. Москва, 1991. С. 255-260.

38 Шитиков М.М. Константинополь и венецианская торговля... С. 49.

39 Карпов С.П. Итальянская торговля в Трапезунде и ее воздействие на экономику поздневизантийского города // Византийский временник. Т. 44. Москва, 1983. С. 81.

40 Balard M. La Romanie Génoise (XIIe - début du XVe siècle), I-II. Rome; Genova, 1978. P. 338.

${ }^{41}$ Карпов С.П. [Рец. на:] M. Balard. La Romanie Génoise (XIIe - début du XVe siècle), I-II. Rome; Genova, 1978 // Византийский временник. Т. 44. Москва, 1983. С. 215.

42 Карпов С.П. Итальянская торговля в Трапезунде... С. 86.

43 Ibid. C. 82.

44 Khvalkov E.A. A Regionalization or Long-Distance Trade? Transformations and Shifts in the Role of Tana in the Black Sea Trade in the First Half of the Fifteenth Century // European Review of History: Revue européenne d'histoire. 2016. 23:3. P. 508-525.

${ }^{45}$ Archivio di Stato di Venezia. Senato, Misti, reg. 59, ff. 52-53.
} 
Tana based on the material of the notarial deeds of the $1430 \mathrm{~s} ; 46$ at the same time these sources do not mention such previously important areas as Astrakhan, Samarkand, and Urgench. Some authors believe that this change in the structure of the Venetian trade and shift to local commodities reflected the general trend of Italian trade in the Black Sea region; the Venetian trade interests increasingly focused on the redistribution of goods originating from the surrounding areas ${ }^{47}$, which was meticulously supervised by the Venetian Senate, which regulated the rules of freight 48 .

The stabilization in the region and the rise of trade was a trend running through the first half of the fifteenth century. From 1405 to 1450, the amount paid on the auction by the Venetian merchants to equip the galleys of Tana equaled $24 \%$ of the whole volume of the Levantine galleys trade; 49 in the 1436-1439 the share of Tana in the Levantine galleys trade was 38\%. Thus, the share of Constantinople (and, hence, the Black Sea) in the Levantine trade of Venice varied from quarter to more than a third of the volume of the Levantine trade $\mathrm{e}^{50}$. The amounts of incanti and trade volume were high ${ }^{51}$. These figures decreased sharply during the years of military turmoil and increased during the rise of trade with the Levant. The size of the sums paid on the auction can serve as an indicator of the vitality of trade relations ${ }^{52}$. Thus, based on these figures (especially for the 14361439), we can infer that the 1430s were the time of the greatest prosperity of the Venetian trade in the Northern Black Sea during the whole fifteenth century.

\section{REFERENCES}

Balard, M. (1978). La Romanie Génoise (XIIe - début du XVe siècle), I-II. Rome; Genova [in French].

Baranov, I.A. (2004). Kompleks tretei chetverti XIV veka v Sudakskoi kreposti [The complex of the third quarter of the XIV century in the Sudak fortress]. Sugdeiskii sbornik, 1, 524-559 [in Russian].

Berindei, M. \& Veinstein, G. (1976). La Tana-Azaq de la presence italienne à l'emprise ottomane (fin XIIIe - milieu XVIe siècle). Turcica, T. VIII/1, 110-201 [in French].

Chistozvonov, A.N. (1977). Italianskaia i niderlandskaia ekonomika i torgovlia [Italian and Dutch economics and trade]. Srednie veka, 41, 34-49 [in Russian].

Heyd, W. (1885). Histoire du commerce du Levant au Moyen âge. Leipzig [in French].

Karpov, S.P. (1978). Venetsiansko-trapezundskii konflikt 1374-1376 gg. i neizvestnyi mirnyi dogovor 1376 g. [Venetian-Trebizond conflict of 1374-1376 and the Unknown peace treaty of 1376]. Vizantiiskii vremennik, 39, 102-109 [in Russian].

Karpov, S.P. (1981). Trapezundskaia imperiia i zapadnoevropeiskie gosudarstva v XIII - XV vv. [The Trebizond Empire and Western European States in the $13^{\text {th }}-15^{\text {th }}$ centuries]. Moscow [in Russian].

Karpov, S.P. (1983). [Review:] Balard, M. (1978). La Romanie Génoise (XIIe - début du XVe siècle), I-II. Rome; Genova. Vizantiiskii vremennik, 44, 215 [in Russian].

Karpov, S.P. (1983). Italianskaia torgovlia v Trapezunde i ee vozdeistvie na ekonomiku pozdnevizantiiskogo goroda [Italian trade in Trebizond and its impact on the economy of the late Byzantine city]. Vizantiiskii vremennik, 44, 81-87 [in Russian].

Karpov, S.P. (1990). Italianskie morskie respubliki i Yuzhnoe Prichernomore v XIII-XV vv. Problemy torgovli. [Italian Maritime Republics and the Southern Black Sea Region in the $13^{\text {th }}-15^{\text {th }}$ centuries. Trade problems]. Moscow [in Russian].

Karpov, S.P. (1991). Dokumenty po istorii venetsianskoi faktorii Tana vo vtoroi polovine XIV v. [Documents on the history of the Venetian trading post of Tan in the second half of the XIV century].

\footnotetext{
46 ASV. NT. Busta 750. 5.

47 Berindei M., Veinstein G. La Tana-Azaq de la presence italienne à l'emprise ottomane (fin XIIIe - milieu XVIe siècle), «Turcica», 1976, T. VIII/1. P. 143.

${ }^{48}$ Berindei M., Veinstein G. La Tana-Azaq de la presence italienne à l'emprise ottomane... P. 142-143.

49 Thiriet F. La Romanie vénitienne au moyen âge / Ed. de Boccard. Paris, 1959. P. 421-422.

50 Шитиков М.М. Константинополь и венецианская торговля... С. 51.

${ }^{51}$ Карпов С.П. Путями средневековых мореходов... С. 120.

52 Шитиков М.М. Константинополь и венецианская торговля... С. 51.
} 
Prichernomore v srednie veka, 1, 191-216 [in Russian].

Karpov, S.P. (1991). Venetsianskii dokument XV v. o torgovoi navigatsii v Vostochnom Sredizemnomore [Venetian document of the $15^{\text {th }}$ century on trade navigation in the Eastern Mediterranean]. Vizantiiskii vremennik, 52, 255-260 [in Russian].

Karpov, S.P. (1994). Krizis Tany $1343 \mathrm{~g} \mathrm{v}$ svete novykh istochnikov [Tana crisis of 1343 in the light of new sources]. Vizantiiskii vremennik, 55, Vol. 1, 121-126 [in Russian].

Karpov, S.P. (1994). Putiami srednevekovykh morekhodov. Chernomorskaia navigatsiia Venetsianskoi Respubliki $v$ XIII-XV $v v$. [Ways of Medieval Sailors: The Black Sea Navigation of the Republic of Venice in the $13^{\text {th }}-15^{\text {th }}$ Centuries]. Moscow [in Russian].

Karpov, S.P. (1997). Porty Peloponnesa v sisteme torgovoi navigatsii venetsianskikh torgovykh galei v Chernom more (XIV-XV vv.) [Peloponnese Ports in the System of Trade Navigation of Venetian Trade Gales in the Black Sea (XIV-XV centuries)]. Srednie veka, 59, 49-59 [in Russian].

Karpov, S.P. (1999). Krizis serediny XIV v.: nedootsenennyi perevorot? [Mid-14th Century Crisis: Underestimated Coup?]. In: Litavrin, G.G. (Ed.). Vizantiia mezhdu Zapadom i Vostokom. Opyt istoricheskoi kharakteristiki, (pp. 220-238). Sankt-Peterburg [in Russian].

Karpov, S.P. (2000). Ot Tany v Urgench - eti trudnye dorogi Srednevekovia [From Tana to Urgench These Difficult Roads of the Middle Ages]. Srednie veka, 61, 215-224 [in Russian].

Karpov, S.P. (2009). Greki i latiniane v venetsianskoi Tane (seredina XIV - seredina XV vv.) [Greeks and Latins in the Venetian Thane (mid-14th - mid-15th centuries)]. Prichernomore $v$ srednie veka, 7, 164173 [in Russian].

Khvalkov, E.A. (2016). A Regionalization or Long-Distance Trade? Transformations and Shifts in the Role of Tana in the Black Sea Trade in the First Half of the Fifteenth Century. European Review of History: Revue européenne d'histoire, 23/3, 508-525 [in English].

Klimanov, L.G. (1998). Obretenie Venetsiei moria: pravo, politika, simvoly [The acquisition of the sea by Venice: law, politics, symbols]. Prichernomore v srednie veka, 3, 145-163 [in Russian].

Kolli, L.P. (1913). Khadzhi-Girei khan i ego politika (po genuezskim istochnikam). Vzgliad na politicheskie snosheniia Kaffy s tatarami v XV veke [Hadji Giray Khan and his politics (according to Genoese sources). A look at the political relations of Kaffa with the Tatars in the $15^{\text {th }}$ century]. Izvestiia Tavricheskoi Uchenoi Arkhivnoi Komissii, 50, $99-139$ [in Russian].

Oikonomides, N. (1979). Hommes d'affaires grecs et latins à Constantinople (XIIIe - XVe siècles). Montreal; Paris. [in French].

Ponomarev, A.L. (1998). Denezhnyi rynok Trapezundskoi imperii v XIII-XV vv. [Money Market of the Trebizond Empire in the $13^{\text {th }}-15^{\text {th }}$ Centuries]. Prichernomore $v$ srednie veka, 3, 201-239 [in Russian].

Prokofeva, N.D. (2000). Akty venetsianskogo notariia v Tane Donato a Mano (1413-1419) [Acts of the Venetian notary in Tan Donato a Mano (1413-1419)]. Prichernomore v srednie veka, 4, 36-174 [in Russian].

Rolova, A.D. (1994). Italianskii kupets i ego torgovo-bankovskaia deiatelnost v XIII-XV vv. [The Italian merchant and his trading and banking activities in the XIII-XV centuries]. Srednie veka, 57, 62-74 [in Russian].

Rutenburg, V.I. (1974). Italiia i Evropa nakanune Novogo vremeni [Italy and Europe on the eve of the New Time]. Leningrad [in Russian].

Shitikov, M.M. (1969). Konstantinopol i venetsianskaia torgovlia v pervoi polovine XV v. po dannym knigi schetov Dzhakomo Badoera [Constantinople and Venetian trade in the first half of the $15^{\text {th }}$ century according to the book of accounts of Giacomo Badoer]. Vizantiiskii vremennik, 30, 48-62 [in Russian].

Skrzhinskaia, E.Ch. (1973). Venetsianskii posol v Zolotoi Orde (po nadgrobiiu Yakopo Kornaro 1362 g.) [Venetian Ambassador to the Golden Horde (on the tombstone of Yacopo Kornaro, 1362)]. Vizantiiskii vremennik, 35, 103-118 [in Russian].

Talyzina, A.A. (2000). Venetsianskii notarii v Tane Kristoforo Ritstso (1411-1413) [Venetian Notary in Tan Cristoforo Rizzo (1411-1413)]. Prichernomore v srednie veka, 4, 19-35 [in Russian].

Thiriet, F. (1959). La Romanie vénitienne au moyen âge. Paris [in French].

Uzlov, Yu.A. (2004). K voprosu ob italianskoi kolonizatsii Severo-Zapadnogo Kavkaza v XIII-XV vv. [On the question of Italian colonization of the Northwest Caucasus in the XIII-XV centuries]. In: Prichernomore Krym Rus v istorii i kulture: materialy II Sudakskoi mezhdunarodnoi nauchnoi konferentsii 1216 sentiabria 2004 g. Vol. II (pp. 213-219). Kiev-Sudak [in Russian].

Vorobeva, I.G. (1987). Venetsianskaia respublika i yugo-slavianskie zemli v XV-XVII vekakh [The Venetian Republic and Southern Slavian's lands in the $15^{\text {th }}-17^{\text {th }}$ centuries]. Kalinin [in Russian]. 


\section{Євген Хвальков}

(Вища школа економіки, Санкт-Петербург, Російська Федерація)

ORCID: https://orcid.org/0000-0003-3688-7638

\section{Торговельне значення венеціанської Тани у 1430-х роках}

У XIII-XV ст. середньовічна Європа домоглася певних успіхів у торгівлі та переході до ринкової економіки, що призвело до створення низки венеціанських і генуезьких заморських колоній у Східному Середземномор'ї та Причорномор'ї. Стабільність Рах Mongolica позитивно позначилася на торгівлі на далекі відстані з Центральною та Східною Азією й Індією. Генуя початку колонізувати цей регіон раніше, ніж її головний конкурент - Венеція. Венеціанці заснували у цьому регіоні свої колонії в Тані і Трапезунді.

У XV ст. товари зі Східної Європи (особливо раби) переважали над товарами 3 Центральної та Східної Азії. Натомість венеціанці та генуезці імпортували до регіону тканини, рис, мило, скло, кераміку, ювелірні вироби та зброю.

Вся зовнішня політика італійських морських республік, по відношенню до східних країн, в основному полягала у тому, щоб забезпечити найбільш сприятливий режим торгівлі й оподаткування: скоротити або скасувати коммеркій, запобігти зловживанням у торгівлі, уніфікувати стандарти збору податків, розширити привілеї, гарантувати безпеку переміщення, а також отримати компенсації. Італійські купці влаштувалися у Північному Причорномор'ї, оскільки татарські хани добре розуміли важливість міжнародної торгівлі на своїй території та можливість прибутків від торгівлі.

У першій половині XV ст. мали місце стабілізація у регіоні та зростання торгівлі. Розміри incanti й обсяг торгівлі були високі. Ці обсяги різко скорочувалися у роки війни та збільшилися у період підйому торгівлі з Левантом. Розмір сум, виплачуваних на аукціоні, може служити індикатором життєздатності торгових відносин. Таким чином, грунтуючись на цих цифрах (особливо за 1436-1439 рр.), можна зробити висновок, що 1430-і роки, ймовірно, були часом найбільшого процвітання венеціанської торгівлі у Північному Причорномор'ї протягом всього XV ст.

Ключові слова: Венеція, Генуя, колонії, Тана, Чорноморський регіон, ринок, міжнародна торгівля 